\title{
Morphology, geometric morphometrics, and taxonomy in relict deciduous oaks woods in northern Italy
}

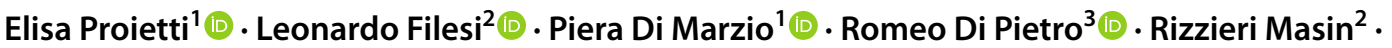 \\ Antonio Luca Conte ${ }^{1}\left[\right.$. Paola Fortini ${ }^{1}[$
}

Received: 9 March 2021 / Accepted: 13 May 2021 / Published online: 3 June 2021

(c) The Author(s) 2021

\begin{abstract}
The Euganean Hills are a well-known refugee site for thermophilous woody flora in northern Italy. Among the species recorded here, there is Quercus dalechampii. The Euganean Hills are the only northern Italy site where the occurrence of this oak species is considered. The aim of this paper was to verify the presence of $Q$. dalechampii in the study area and to select possible diagnostic morphological traits that are usable to distinguish it from $Q$. petraea and $Q$. pubescens. Forest stands dominated by $Q$. petraea, $Q$. pubescens, and the presumed $Q$. dalechampii were sampled using the phytosociological approach to highlight their ecological features. Leaf and fruit material from 104 oak individuals was analysed from a macromorphological and micro-morphological point of view. Leaf shape was also analysed using the geometric morphometric approach. All multivariate analysis procedures applied on the matrices of leaf and fruit traits highlighted two main clusters of morphological diversity. One was restricted to $Q$. pubescens individuals, and the other one was a mix of $Q$. petraea and presumed $Q$. dalechampii individuals. According to the twig and leaf trichome traits, all presumed $Q$. dalechampii individuals were classified as belonging to the $Q$. petraea collective group. Morphological differences between $Q$. petraea and presumed $Q$. dalechampii were considered not significant. In conclusion, the occurrence of a third oak species, in addition to $Q$. petraea and $Q$. pubescens, was not confirmed for the study area by the results of this paper.
\end{abstract}

\section{Graphic abstract}

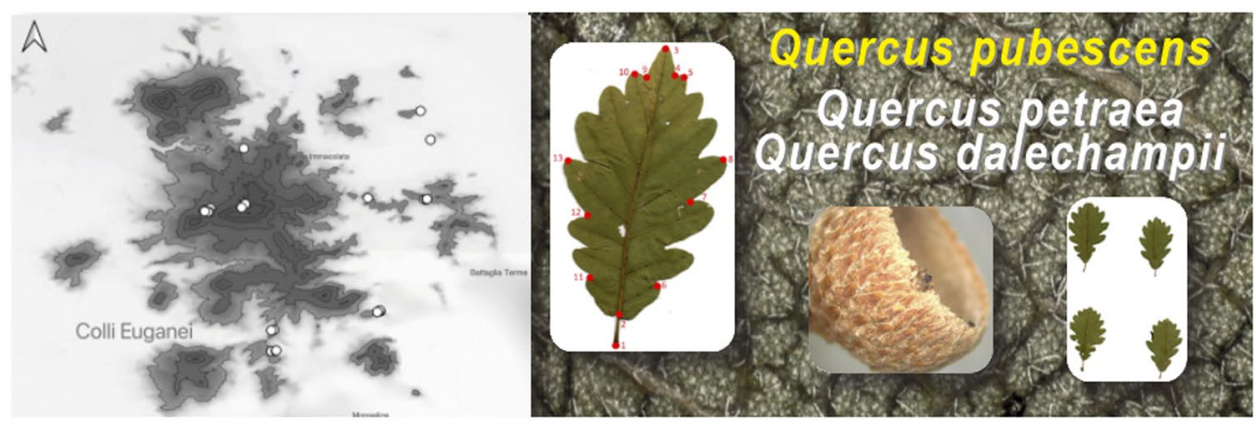

Keywords Biogeography $\cdot$ Euganean hills $\cdot$ Quercus dalechampii $\cdot$ Southern Europe $\cdot$ Taxonomy $\cdot$ White oaks

Romeo Di Pietro

romeo.dipietro@uniroma1.it

Elisa Proietti

elisaproietti91@gmail.com

Leonardo Filesi

leonardo@iuav.it

Piera Di Marzio

piera.dimarzio@unimol.it

Rizzieri Masin

mas.roberto@libero.it
Antonio Luca Conte conte.antonio79@gmail.com

Paola Fortini fortini@unimol.it

1 Department of Bioscience and Territory, University of Molise, 86090 Pesche, IS, Italy

2 University IUAV of Venice, 30135 Venice, Italy

3 Department PDTA, University of Rome Sapienza, 00196 Rome, Italy 


\section{Introduction}

Quercus petraea (Matt.) Liebl. and Q. pubescens Willd. are two deciduous species of the genus Quercus L. subgenus Quercus Oerst, which play a primary role in the thermophilous forest ecosystems of Europe (Caudullo et al. 2016; Mucina et al. 2016; Pasta et al. 2016). Gene flow is a common phenomenon in oaks, especially in white oaks, owing to the absence of real reproductive barriers within the genus (Burger 1975; Spellenberg 1995; Gonzàles-Rodrìguez et al. 2004). Nevertheless, interfertile oak species seem to remain separate and well-identifiable taxonomical units, even in situation of sympatry (Muir et al. 2000; Muir and Schlötterer 2005; Valbuena-Carabaña et al. 2005, 2007; Curtu et al. 2007; Gugerli et al. 2007; Fortini et al. 2015). Other authors, however, are more inclined to consider most oak individuals occurring in natural populations as hybrid forms containing, case by case, variable percentages of the parental genome (Kissling 1983; Minihan and Rushton 1984; Hipp et al. 2019). Problems arise when the taxonomical identification of oak individuals is based exclusively on the observation of morphological traits (Bruschi et al. 2000; Borazan and Babaç 2003; Curtu et al. 2007; Hipp 2015, Musarella et al. 2018). These problems become even more complicated when the identification process is carried out on individuals collected in oak forests where more species belonging to taxonomically intricate collective oak groups grow together (see Di Pietro et al. 2016, 2020a, b, c). Problems become almost unsolvable when nomenclatural complications arise, for instance, protologues that do not stand out for clarity or for consistency with the original material. Emblematic is the case of Quercus dalechampii Ten., which, according to the protologue (Tenore 1830), would fall within the collective group of $Q$. petraea s.l., whereas the morphological characteristics displayed by the majority of the original material would address it to the collective group of $Q$. pubescens s.l. (cfr. Camus 1938-1939; Schwartz 1993; Brullo et al. 1999). This misunderstanding has gradually fossilised over time and led to the paradoxical situation in which some European countries (especially in eastern-Europe) used the name $Q$. dalechampii to identify a species having glabrous leaves and twigs, while other European countries (especially Italy) adopted the same name to identify a clearly different species having pubescent leaves and twigs. This issue has implications that are not limited to the purely taxonomic field if we consider that $Q$. dalechampii is currently reported as a diagnostic species in two habitats of the 92/43/EU Directive (EU 2014 Manual of Interpretation). The case of $Q$. dalechampii was solved (at least from a nomenclatural point of view), providing an unambiguous lectotypification (Di Pietro et al. 2012) that addressed this name to the collective group of pubescent oaks ( $Q$. pubescens s.1.). It remains to be defined where $Q$. dalechampii belongs from a systematic point of view, or in broad terms, whether the name $Q$. dalechampii corresponds to living material deserving a real taxonomical value. In Italy, $Q$. dalechampii is especially known for central and southern Italy, where it acts as high-frequency species in various phytosociological associations. The distribution of $Q$. dalechamoii in northern Italy is not perfectly known (Bartolucci et al. 2018), and the few available references never provide certainty about its actual occurrence. The northern Italy area for which $Q$. dalechampii is mentioned (directly or indirectly) most frequently is the Euganean Hills (Colli Euganei). These are an isolated group of volcanic hills emerging from the Venetian Valley that are currently completely surrounded by extensive cultivated crops. The Euganean hills slopes are covered by natural oak forests and chestnut woods deriving from ancient plantations that progressively replaced the pre-existing deciduous oak forests (Gubler et al. 2018). Masin and Tietto (2005), in their study on the flora of the Euganean Hills, reported $Q$. dalechampii as a species commonly found in thermophilous forest habitats. The same authors confirmed this datum in a subsequent paper concerning the Flora of the whole Administrative Province of Padua (Masin and Tietto 2006). Argenti et al. (2019) considered $Q$. dalechampii (under the binomy $Q$. aurea Wirzb.) as occurring not only in the Euganean Hills area but also within the S-facing slopes of several eastern Prealps valleys. Buffa et al. (2016) included Q. dalechampii in the red list of the vascular plants of the Veneto administrative Region and indicated the Euganean Hills as the only site where the species was present with certainty. Finally, according to Buffa and Lasen (2010) and Biondi et al. (2010), the Euganean Hills host the oak forest habitat 91AA*_Eastern white oak woods. The diagnosis of this habitat is: "Mediterranean and sub-Mediterranean Adriatic and Tyrrhenian woods dominated by Quercus virgiliana, Q. dalechampii, $Q$. pubescens, and Fraxinus ornus, indifferent to soil type, thermophilous and often in edaphic-xerophilous position typical of Italian peninsula but with affinity with the Balkan ones". However, the presence of this Habitat in northern Italy is still a controversial topic, so any revisions providing clarification on the taxonomic identity of the guide species of these oak forests or their ecological, biogeographic, and syntaxonomic features could assume a discriminating role in addressing management and conservation policies. It is not a case that floristic and vegetational gaps of knowledge and scarce availability of spatial and quantitative data are considered the main reasons affecting the application of the criteria adopted for the identification and assessment of European Habitats (Gigante et al. 2018; Carli et al. 2020). Due to their particular geographical location, the Euganean Hills proved to be an important refuge site for both thermophilous and microthermic woody species. In this paper, we tried to understand whether the peculiar combination of morphological and bioclimatic factors that characterise 
the Euganean Hills could have selected possible thermophilous oak ecotypes or something of even more relevance from a taxonomic point of view. According to Costantini et al. (2005), the distribution of the deciduous oak forests in the Euganean Hills provide for $Q$. petraea woods in the upper part of the hills on volcanic substrates and $Q$. pubescens woods at lower altitudes on limestone outcrops. Both forest types were reported as including $Q$. dalechampii, which, in turn, would act as guide species of a third oak forest type occurring in an intermediate altitudinal position between the two aforementioned forest types, especially on acidic volcanic soils (ARPAV 2013). The aim of this study is to understand: (1) whether these three types of oak forests are effectively referable to three different oak species; and (2) whether these three oak species prove to be distinguishable from each other on the basis of an unequivocal combinations of morphological traits.

To reach these goals, different oak populations were sampled in the Euganean Hills area, and a data set of leaf and fruit morphological traits was prepared and statistically analysed. Leaves were also analysed using geometric morphometric methods (GMMs).

\section{Study area}

The Euganean Hills are a group of low mountains (the highest culmination is Monte Venda, $601 \mathrm{~m}$ a.s.l.) located in the Venetian Plain (the eastern part of the Po river Plain) and isolated from surrounding hilly or mountainous massifs (Fig. 1). The Quaternary evolution of the Venetian Plain is strongly related to the response of alluvial systems to climate and sea-level changes (Fontana et al. 2010). The Euganean Hills extend for about $187 \mathrm{~km}^{2}$ and are characterised by a mild morphology and heterogeneous lithological substrates composed of the alternation of magmatic rocks (mainly rhyolite and trachyte) and sedimentary rocks, such as red scale, majolica, and pelithic-areanaceous marls (Pellegrini et al. 2004). The climate is sub-continental temperate with a significantly lower incidence of fog and a lower annual temperature excursion when compared with the surrounding Venetian Plain (Masin et al. in press). The Galzignano Terme thermo-pluviometric station (Online Resource 1) reported a mean annual temperature of $13.6{ }^{\circ} \mathrm{C}$ and an annual rainfall of $839 \mathrm{~mm}$ (it.climate-data.org).

\section{Material and methods}

In Autumn 2019, 104 deciduous oak individuals were sampled within the Euganean Hills natural oak forest stands along an altitudinal gradient ranging between 50 and $550 \mathrm{~m}$. a.s.l. (Table 1). Specimens of three taxonomically critical species, namely Quercus pubescens, $Q$. petraea, and presumed $Q$. dalechampii (in the rest of the text the term "presumed" will be omitted and the species will be reported as $Q$. dalechampii only) were collected and analysed from a morphological and morphometric viewpoint. The preliminary assignment of the collected specimens to one or the other of these three taxa was based on two criteria: (1) the expert floristic knowledge in the Euganean Hills area of two of the authors, and (2) what is currently reported by taxonomic and vegetation science literature on the geographical and ecological location of $Q$. dalechampii woods in the Eugenean Hills (see "Introduction" paragraph). The three oak species investigated showed a well-defined distribution pattern linked to lithology, altitude, and exposure. $Q$. pubescens (PUB) was found at a very low altitude on neutralalkaline substrates, such as fine grain limestone (Maiolica) and pinkish marly limestone (scaglia rossa). A second
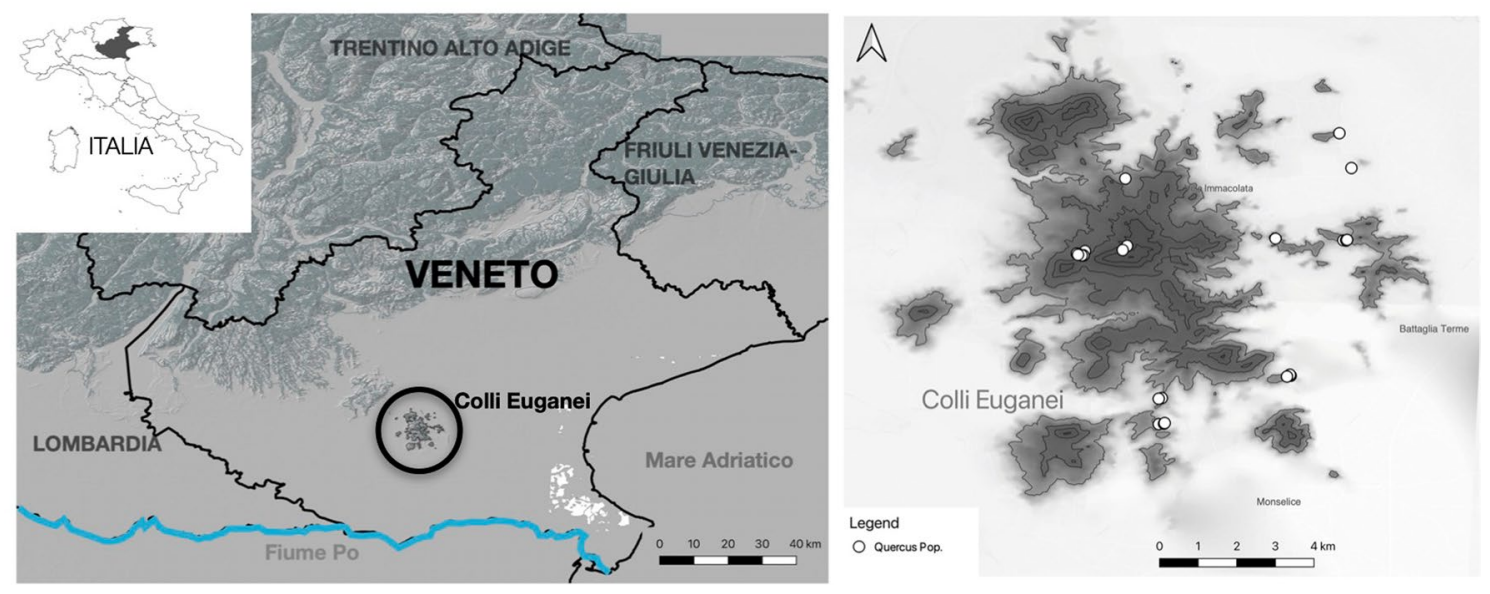

Fig. 1 Position of the study area in NE-Italy (left side) and distribution of the sites of collection (right side-white circles) of the three oak species investigated: $Q$. petraea, $Q$. pubescens, presumed $Q$. dalechampii 
Table 1 Description of sampled trees and sampling locations

\begin{tabular}{|c|c|c|c|c|c|}
\hline Sampled tree codes & Species & Location & $\begin{array}{l}\text { Municipality } \\
\text { (Province of Padua) }\end{array}$ & Altitude (m a.s.l.) & Substrate \\
\hline PUB01 to PUB14 & Quercus pubescens & M. Calbarina & Arquà Petrarca & $75-90$ & Limestone marl (majolica) \\
\hline PUB15 to PUB22 & & Ca' Chimelli & Baone & $75-85$ & Limestone marl (majolica) \\
\hline PUB23 to PUB25 & & Ca' Chimelli/Comezzare & Baone & 60 & Limestone marl (majolica) \\
\hline PUB26 to PUB35 & & Pajone & Arquà Petrarca & $80-95$ & Limestone (red scale) \\
\hline DAL01 to DAL04 & Quercus dalechampii & Colle S. Daniele & Abano Terme & 50 & Rhyolite \\
\hline DAL05 to DAL08 & & M. Ortone & Teolo & 80 & Rhyolite \\
\hline DAL09 & & M. Zogo & Torreglia & 100 & Trachy-Rhyolite \\
\hline $\begin{array}{l}\text { DAL10 to DAL19, } \\
\text { DAL22 to DAL25 }\end{array}$ & & M. Alto (Regazzoni) & Montegrotto Terme & $150-180$ & Trachy-Rhyolite \\
\hline $\begin{array}{l}\text { DAL20, DAL21, DAL26 } \\
\text { to DAL33 }\end{array}$ & & M. Trevisan & Montegrotto Terme & $160-175$ & Rhyolite \\
\hline PET01 and PET02 & Quercus petraea & M. Venda & Teolo & 500 & Rhyolite \\
\hline PET03 & & M. Venda & Vò & 500 & Rhyolite \\
\hline РET04 & & M. Venda & Vò & 550 & Rhyolite \\
\hline PET05 & & Roccapendice & Teolo & 150 & Trachyte \\
\hline PET06 to PET36 & & Laghizzolo & Vò & $320-355$ & Rhyolite \\
\hline
\end{tabular}

group, identifiable as $Q$. petraea (PET) occurred at the top of gorges on shallow soils or within the bottom of the valleys on deeper soils, and developed on volcanic substrates, especially rhyolite and trachyte. A third group, referable to $Q$. dalechampii (DAL), occurred at a lower altitude and developed on rhyolite and trachyte. The three types of oak forests were subjected to vegetation sampling to provide an ecological and coenological outline for each of the three oak species investigated. Vegetation samples were performed using the phytosociological approach (Braun-Blanquet 1964). Both syntaxonomic classifications of the species and nomenclature of syntaxa in the phytosociological table made reference to Mucina et al. (2016).

The sampling of individuals for taxonomic purposes was carried out by maintaining a distance of at least $20 \mathrm{~m}$ from one individual to another. Where possible, individuals were selected among those bearing fruits. Voucher specimens were deposited in the herbarium of the University of Molise (IS) (Thiers 2015).

\subsection{Assessment of pubescence}

For each individual tree, the degree of pubescence of young twigs (TP) and leaf buds (BP) was assessed using a grading system applied on a standard area of $1 \mathrm{~mm}^{2}$ (Online Resource 2). The same grading system (standard area of $1 \mathrm{~mm}^{2}$ ) was used for micro-morphological analysis of the eu-glandular trichomes occurring on the lower side of the leaf, in accordance with the protocol published in Fortini et al. (2009). Two types of arrangements of eu-glandular trichomes were established: stellate trichomes $(\mathrm{StH})$ and fasciculate trichomes (FH) (Online Resource 2).

\subsection{Assessment of leaf traits}

Nine leaves per individual tree were analysed. These leaves were scanned by placing the abaxial surface facing upwards on an Epson GT-15000 scanner (300 dpi resolution). Leaves were subsequently measured with an ImageJ instrument (Rasband 1997-2007). In total, 9 leaf traits were assessed, of which five 'dimensional' (petiole length-PL, lamina length-LL, lobe width-LW, the corresponding sinus width-SW, and the height of the widest point from the base of the leaf-WP) and four 'transformed' traits (obversity - OB, petiole ratio- $-\mathrm{PR}$, lobe depth ratio- - LDR, and lobe width ratio_-LWR) sensu Kremer et al. (2002) (Online Resource 2).

The type of basal shape of the leaf lamina (types ranging from 1 to 9) was established using Kremer's index (Kremer et al. 2002) (Online Resource 3).

\subsection{Assessment of fruit traits}

A study was performed analysing eleven diagnostic morphological traits of the fruit (Fortini et al. 2015): four-dimensional traits (cupule length-CL, cupule width-CW, acorn length - AL, and acorn width-AW), two transformed traits (CW/CL and CL/AL), and five ordinal traits (regularity of 
cupule edge- $-\mathrm{RCE}$, cupule scale shape-SS, gibbosity-G, cupule intern hairness- $\mathrm{CIH}$, and type of cupule edgeTCE) (Online Resource 2).

The data sets, organised in five matrices (Table 2), were then subjected to univariate statistical analysis (normality tests, Kruskal-Wallis test for independent samples with Dunn multiple comparisons, and the Bonferroni correction of the significance level) using XLSTAT 2020.5.1 (Addinsoft 2020) and multivariate (clustering and ordination) statistical analysis using PAST 4.04 (Hammer et al. 2001). Three groups of individuals belonging to the three oak species investigated and related to the three different environmental conditions characterizing these species were superimposed in both classification and ordination diagrams and marked with different colours: Quercus petraea (blue), $Q$. pubescens (green), and $Q$. dalechampii (red).

\subsection{Leaf geometric morphometric analysis}

The leaf shape of the entire dataset (936 leaves) was analysed using geometric morphometrics (GMMs) analysis of landmarks (Klingenberg et al. 2012; Silva et al. 2012) and following three main steps: (1) scanning of leaves; (2) acquiring a 2D landmarks configuration using tpsDig2 2.31(Rohlf 2015); and (3) statistical analyses. Thirteen landmarks were selected to capture the main features of the leaf shape (Fig. 2). Landmarks 1-3 were 'unpaired landmarks' and were located on the middle axis of the leaf; landmarks 4-13 were 'paired' landmarks and occurred on both sides of the leaf (Savriama and Klingenberg 2011). The TPS file was converted to an NTS file through tpsUtil 1.78 software (Rohlf 2019).

Statistical analyses were carried out using MorphoJ software (Klingenberg 2011) (Table 3). The matrix of the raw

Table 2 Description of the morphological data matrices and related analyses

\begin{tabular}{lllll}
\hline Matrix & Dimensions & Univariate statistical analysis & Clustering options & Ordination \\
\hline Leaves & 104 trees $\times 9$ continuous variables & Normality tests & Gower distance (usable for con- & PCA with correlation \\
Trichomes & 104 trees $\times 4$ ordinal variables & Kruskal-Wallis test & tinuous and ordinal data) and & None \\
Fruits & 68 trees $\times 11$ variables $(6$ continu- & $\begin{array}{c}\text { Dunn multiple comparison with the } \\
\text { Bonferroni correction }\end{array}$ & UPGMA & PCA with correlation \\
& $\begin{array}{c}\text { ous and } 5 \text { ordinal variables) } \\
\text { All }\end{array}$ & & & 100 bootstrap \\
& trees $\times 24$ variables $(15$ con- & & & PCA with correlation \\
\end{tabular}

Fig. 2 Configuration of the 13 leaf blade landmarks under an abaxial view

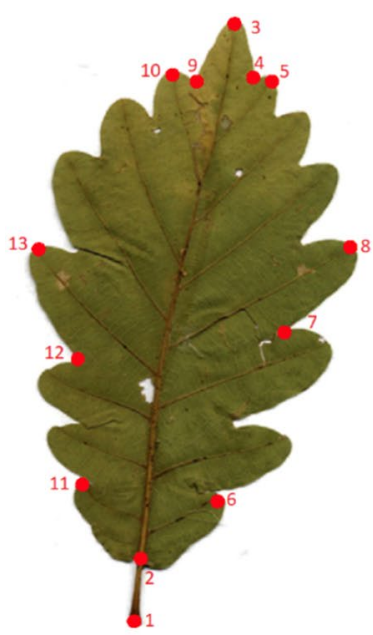

LM1

LM2

LM3

LM4, LM9

LM5, LM10

LM6, LM11

LM7, LM12

LM8, LM13
Beginning of the petiole.

Petiole-leaf blade junction.

Apex of the leaf blade.

Base of the sinus immediately above the apex of the leaf blade.

Tip of the lobe immediately above the apex of the leaf blade.

Tip of the first basal lobe, starting from the petiole.

Base of the sinus immediately above the lobes of the landmarks 8 and 13, respectively.

Tip of the lobe at the largest width of the leaf blade.

Table 3 Description of the morphometric data matrices and related analyses

\begin{tabular}{|c|c|c|c|c|c|}
\hline Matrix & Dimensions & Analysis & & & \\
\hline Raw coordinates-RCM & $\begin{array}{c}936 \text { leaves } \times 26 \\
\text { coordinate }\end{array}$ & New procrustes fit & Outlier analysis & Covariance matrices & PCA \\
\hline Consensus coordinates $-\mathrm{CCM}$ & $\begin{array}{l}27 \text { consensus } \\
\text { leaves } \times 26 \text { coor- } \\
\text { dinates }\end{array}$ & New procrustes fit & Outlier analysis & Covariance matrices & PCA \\
\hline
\end{tabular}


coordinates of the landmarks (RM) $(936$ leaves $\times 26$ coordinates) was imported and a 'New Procrustes Fit' was performed to separate the variation into symmetric and asymmetric components of aligned configurations to reduce the variation caused by developmental noise and instability (Viscosi 2015). Outliers identified in preliminary operations were subsequently excluded from further analyses. Covariance matrices were generated and subjected to PCA. Furthermore, to reduce the effect of the leaf size, a second matrix called consensus (or average) configuration matrix (CCM) was computed for each of the three groups using the nine leaves of each tree in order of decreasing relative size (evaluated on the dimension of lamina length-LL). A 27 (consensus leaves) $\times 26$ (coordinates) matrix was created and all analyses reiterated (Table 3 ).

\section{Results}

\subsection{Vegetation}

\subsubsection{Coenological and phytosociological features}

Based on the Euroveg checklist (Mucina et al. 2016), the woods dominated by the three species investigated were sorted into three classes: Quercetea robori-petraeae, Quercetea pubescentis, and Carpino-Fagetea. Due to the low altitude development of the Euganean Hills, the woods of the three oak species investigated in this study were distributed in close spatial contact with each other; therefore, their floristic composition showed important admixtures. Generally, in all three types of forest, the occurrence of other woody species, such as Fraxinus ornus, Acer campestre, Sorbus torminalis, and Mespilus germanica, was observed. According to Buffa and Lasen (2010), most of the woods dominated by $Q$. petraea occurring in the Euganean Hills should be included in the association MelampyroQuercetum petraeae (Online Resource 4 columns 1-5). This association was already reported by Tasinazzo and Fiorentin (2000) for the Berici Hills (another group of low hills located north of the Euganean Hills and in direct contact with the Venetian pre-Alps) and included in the order Quercetalia roboris. The Euganean Hills Quercus petraea woods exhibits a more mesophilous character when compared with the woods of $Q$. dalechampii and $Q$. pubescens, which is testified by the occurrence of microthermic species, such as Fagus sylvatica, Acer pseudoplatanus, Epimedium alpinum, and Polygonatum multiflorum. Moreover, they exhibit a typical acidophilic character, testified by the codominance in the upper tree layer of Castanea sativa and the occurrence in the undergrowth of Calluno-Ulicetea species, such as Pteridium aquilinum, Vaccinium myrtillus, Festuca heterophylla, Carex pallescens, and C. pilulifera. In addition, we identified some $Q$. petraea wood stands belonging to the alliance Erythronio-Carpinion (Online Resource 4 col. 1-5), which are developed at the bottom of the valleys and characterised by an herb layer, dominated by species such as Anemonoides nemorosa, A. ranunculoides, Stellaria holosteum, and Erythronium dens-canis. The woods dominated by Quercus pubescens (Online Resource 4 col. 13-17) and those dominated by $Q$. dalechampii (Online Resource 4 rel. 6-12) are significantly more thermophilous than the $Q$. petraea ones, as testified by the occurrence of species typical of the evergreen sclerophyllous Mediterranean maquis, such as Arbutus unedo, Cistus salvifolius, and Erica arborea. Moreover, they are characterised by a richer shrub layer (Ligustrum vulgare, Crataegus monogyna, Lonicera caprifolium, and Cornus mas). Compared to the $Q$. petraea woods, the $Q$. dalechampii ones exhibit a slightly less marked acidophilic character, testified by the occurrence of Genista germanica, Cytisus nigricans, and Hieracium racemosus, and a more thermophilous character, which suggests that it should be classified in the alliance Physospermo-Quercion petraeae (Quercetalia pubescenti-petraeae). The $Q$. pubescens woods were developed on limestone substrates and, therefore, exhibit a basiphilous character expressed by Ostrya carpinifolia in the upper tree layer and by Cotinus coggygria, Asparagus acutifolius, and Emerus majus in the shrub layer. This led us to provisionally classify them in the alliance Orno-Ostryon (Quercetalia pubescenti-petraeae).

\subsection{Taxonomy}

\subsubsection{Univariate analysis}

The Kruskal-Wallis test (Online Resources 5, 6, 7) showed differences that were not significant when comparing the $Q$. petraea (PET) and the $Q$. dalechampii groups (DAL), and significant when comparing both these two groups with the Q. pubescens group (PUB). These differences regarded the following traits: pubescence (degree of pubescence of leaf, twig and bud; eu-glandular trichome type of the leaf), fruit (morphological traits of acorn and cupule), and leaf (morphological traits).

\subsubsection{Multivariate analysis}

4.2.2.1 (pubescence) Cluster analysis showed two wellidentifiable groups $\left(\mathrm{A}_{\mathrm{p}}\right.$ and $\left.\mathrm{B}_{\mathrm{p}}\right)$. Group $\mathrm{A}_{\mathrm{p}}$ was composed of all $Q$. pubescens individuals, with the addition of one individual belonging to the $Q$. dalechampii group (DAL17). Group $\mathrm{B}_{\mathrm{p}}$ was composed of all $Q$. petraea individuals together with the remaining $Q$. dalechampii individuals (Fig. 3). 


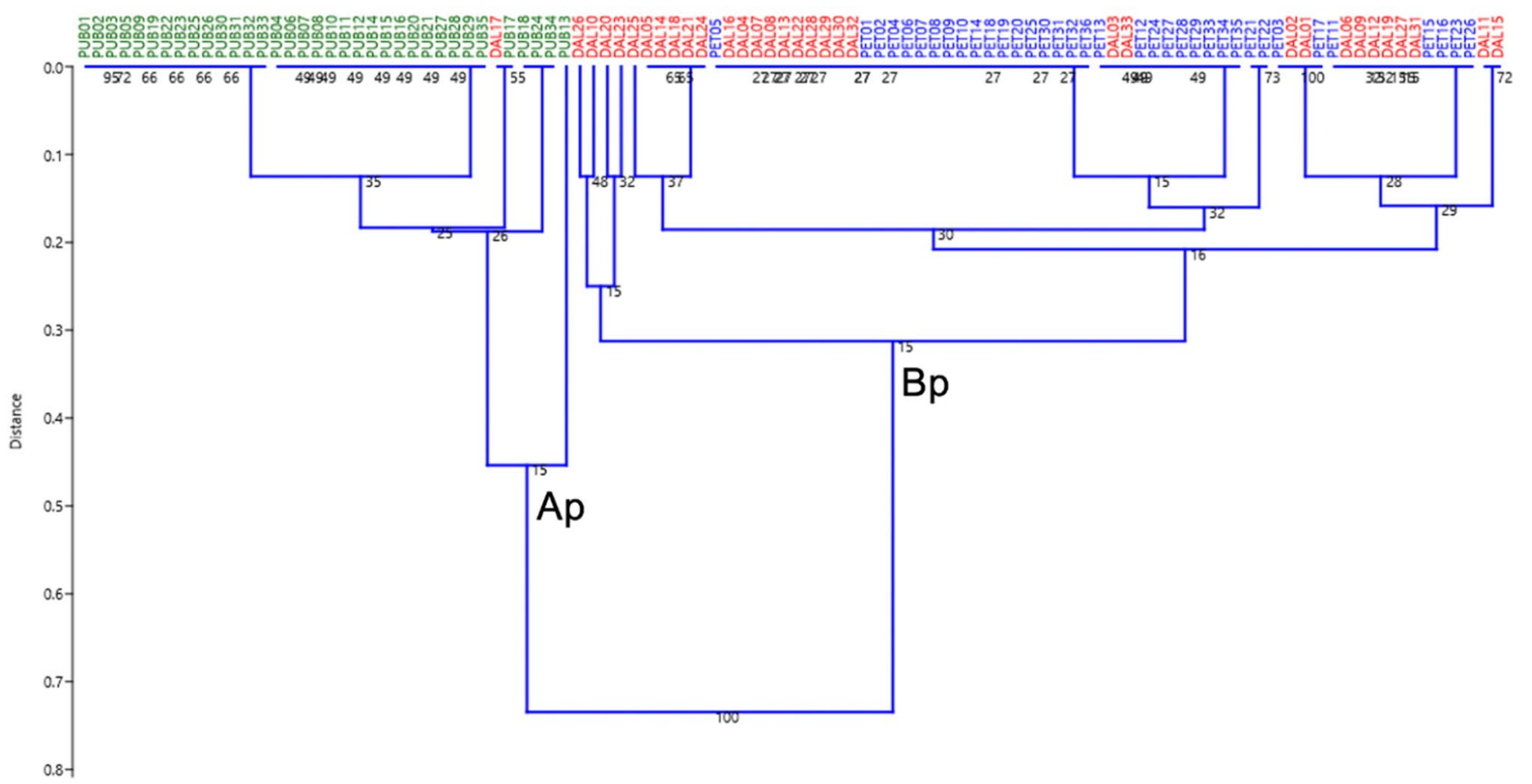

Fig. 3 Clustering of the 104 trees using the five variables for pubescence. Gower distance and UPGMA; 100 bootstraps. Cophenetic correlation $=0.9403$. $Q$. petraea (blue), Q. pubescens (green), and $Q$. dalechampii (red)

4.2.2.2 (fruit traits) The dendrogram showed the occurrence of two main groups $\left(\mathrm{A}_{\mathrm{f}}\right.$ and $\left.\mathrm{B}_{\mathrm{f}}\right)$. $\mathrm{A}_{\mathrm{f}}$ was composed of $Q$. pubescens individuals only, and $\mathrm{B}_{\mathrm{f}}$ was composed of all Q. petraea and Q. dalechampii individuals together with three $Q$. pubescens individuals, namely PUB30, PUB33, and PUB34 (Fig. 4).

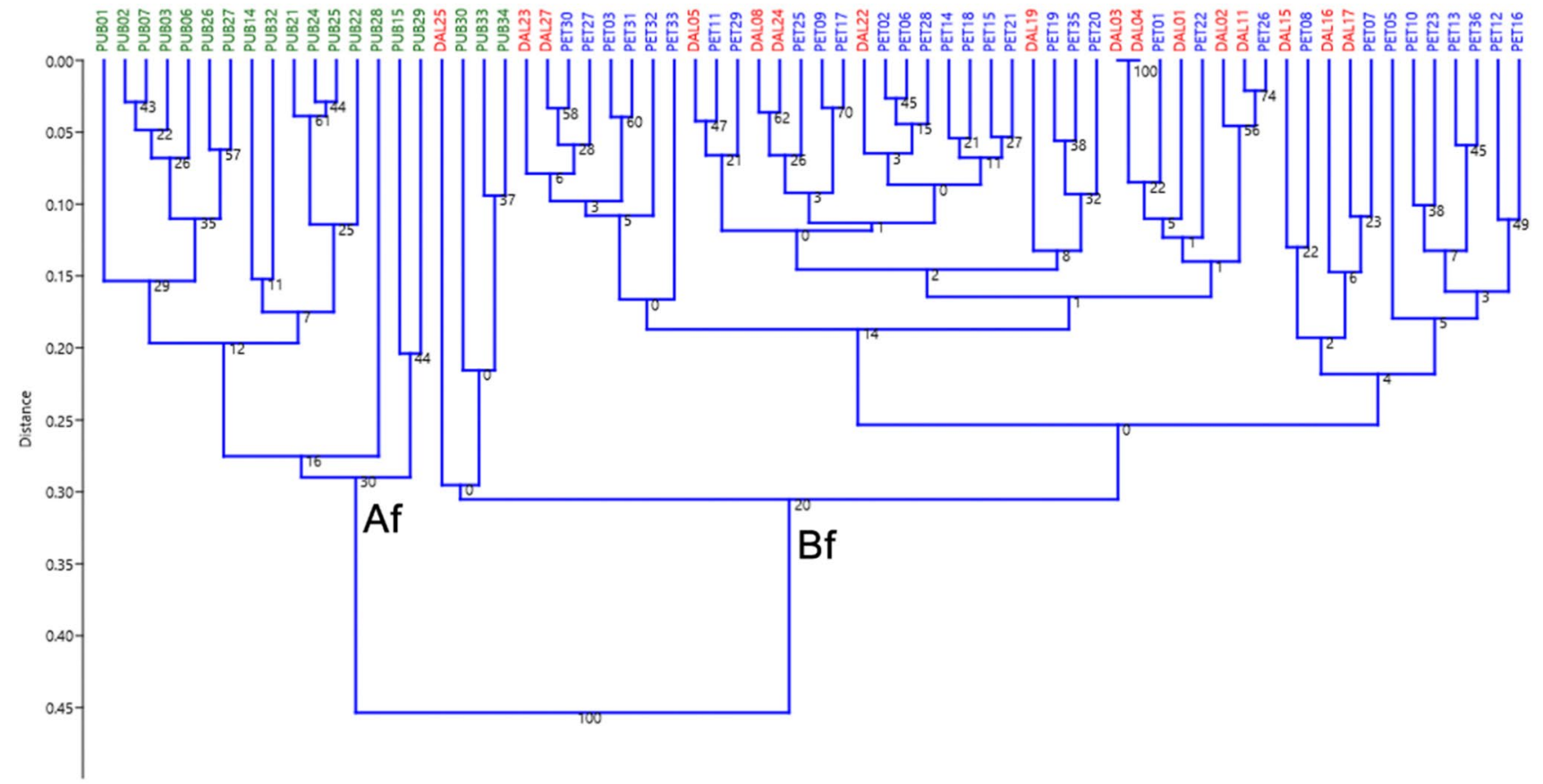

Fig. 4 Clustering of the 68 trees using the eleven variables of fruits. Gower distance and UPGMA; 100 bootstraps. Cophenetic correlation $=0.872$. $Q$. petraea (blue), $Q$. pubescens (green), and $Q$. dalechampii (red) 


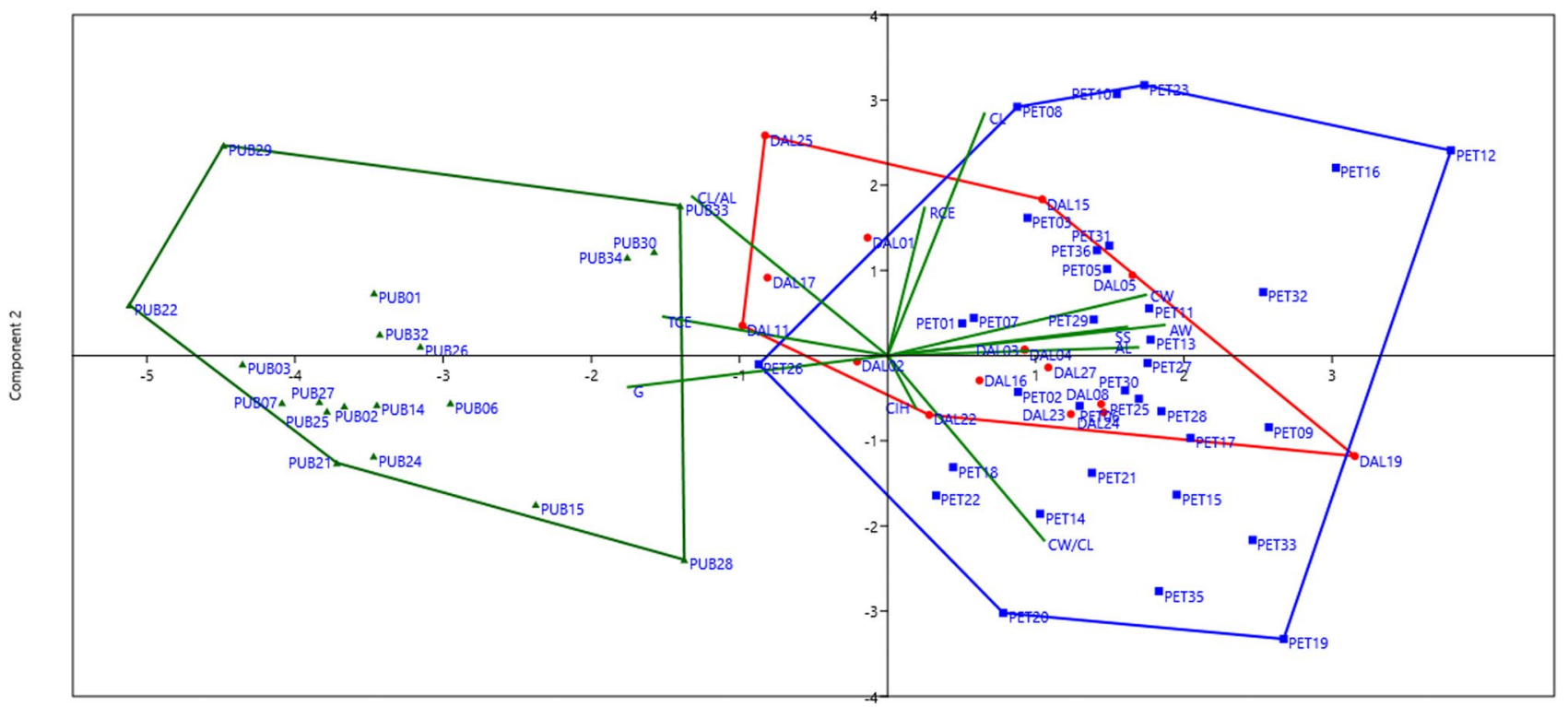

Component 1

Fig. 5 Scattergram of the 68 trees using the eleven variables of fruits. Quercus petraea (blue square), Q. pubescens (green triangle), and Q. dalechampii (red dot)

In the PCA concerning the fruit traits (Fig. 5), the two main principal components accounted for $47.14 \%$ (component 1 ) and $18.83 \%$ (component 2) of the total variance. The PCA output confirmed the results of the dendrogram, displaying a clear division into two groups, where $Q$ pubescens was separated from $Q$ petraea and $Q$. dalechampii. The most discriminant traits identified along component 1 were the pyriform cupule scale shape and the values of cupule and acorn width, which were larger for $Q$. petraea and $Q$ dalechampii individuals, while the presence of gibbosity and the type of cupule edge with scales slightly protruding were the discriminant traits for the $Q$. pubescens individuals.

4.2.2.3 (leaf traits) The cluster analysis based on the leaf traits showed one outlier ( $Q$. petraea PET14) and two principal groups $\left(\mathrm{A}_{1}\right.$ and $\left.\mathrm{B}_{1}\right)$. Group $\mathrm{A}_{1}$ was mainly composed of $Q$. pubescens individuals together with three $Q$. petraea individuals, PET02, PET25, and PET27, and three Q. dalechampii individuals (DAL10, DAL22, and DAL25). Group $\mathrm{B}_{1}$ was composed of the majority of $Q$. petraea and $Q$. dalechampii individuals and four $Q$. pubescens individuals (PUB08, PUB10, PUB11, and PUB12) (Fig. 6).

In the PCA based on the leaf traits (Fig. 7), the two main principal components accounted for $50.33 \%$ (component 1 ) and $15.50 \%$ (component 2) of the total variance. A continuous pattern of distribution of the individuals was identified along PCA component 1 . However, the individuals of $Q$. pubescens were distributed on the left side of the diagram, whereas the central and right parts of the diagram were occupied by $Q$. petraea and $Q$. dalechampii individuals.
Only a limited overlap was evidenced between the $Q$. pubescens and the $Q$. petraea-Q. dalechampii groups, whereas an almost complete overlap was displayed between the $Q$. petraea and $Q$. dalechampii groups. Although there was partial isolation of the $Q$. pubescens group of individuals on the left side of the diagram, no specific leaf traits were involved in the separation between this group and the $Q$. petraea- $Q$. dalechampii group. The distribution of individuals along PCA component 2 was characterised by a large overlap of the three identified groups.

In the pie charts, scoring on the shape of the basal part of the leaf from the three groups of individuals (Q. petraea, $Q$. pubescens, and $Q$. dalechampii) displayed the absence of a correspondence between Quercus species and a single type of basal part of the leaf shape. Each of the three species exhibited up to six shapes of the basal part of the leaf, and these six shapes were shared (in different percentages) by all the species (Online Resource 8).

\subsubsection{Leaf geometric morphometrics results}

Preliminary analyses showed an outlier (leaf PET07), which was removed from subsequent analyses. The scatterplot of the PCA computed on the symmetric components of the raw matrix (RCM) showed a significant overlap between the leaves of the three groups ( $Q$. petraea, $Q$. pubescens, and $Q$. dalechampii). Conversely, the scatterplot of the PCA computed on the symmetric component of CCM exhibited a sufficiently clear discrimination of the three groups along the first axis, explaining $57.5 \%$ of the total symmetric variation, 


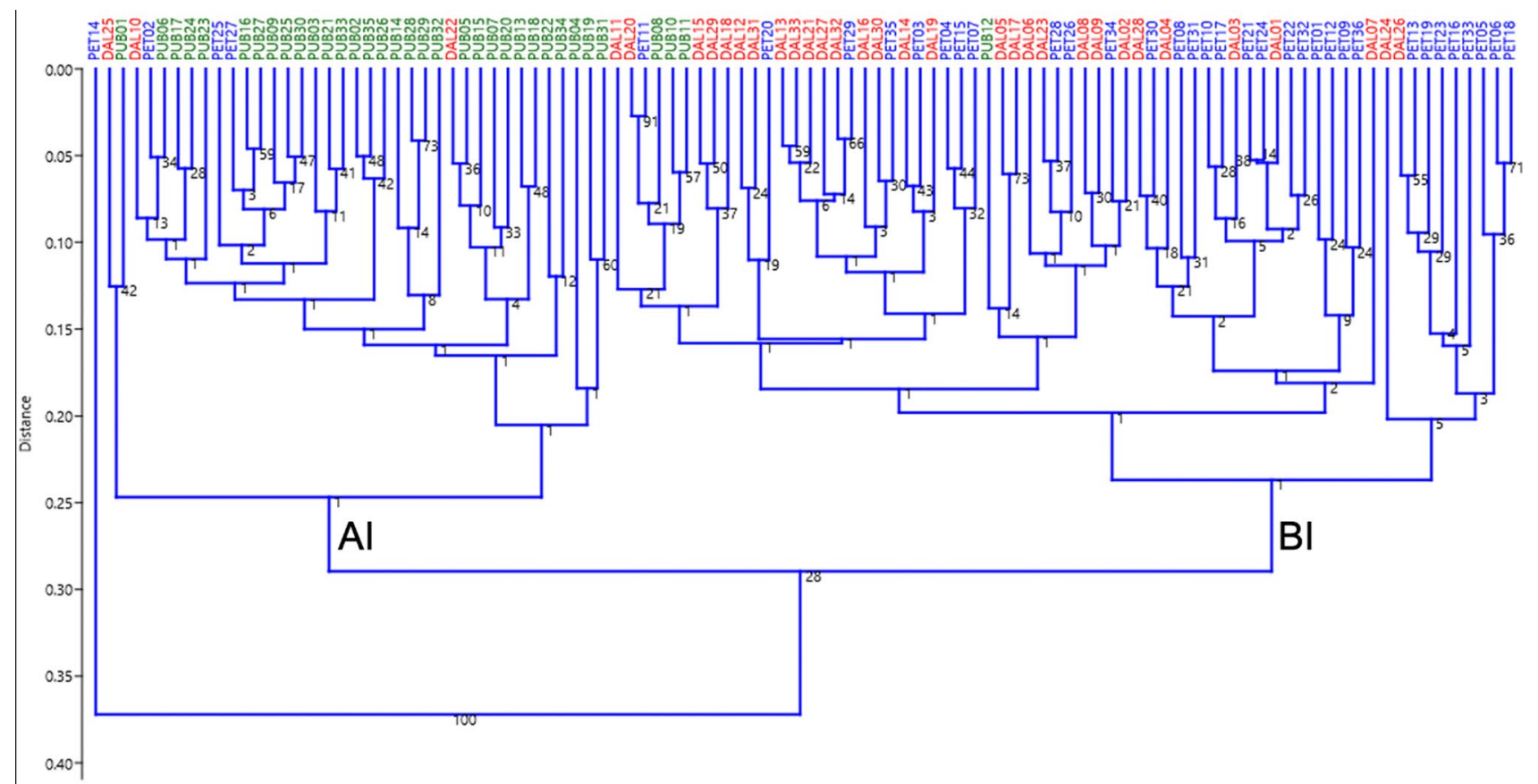

Fig. 6 Clustering of the 104 trees using the nine variables of leaves. Gower distance and UPGMA; 100 bootstraps. Cophenetic correlation $=0.6732$. $Q$. petraea (blue), $Q$. pubescens (green), and $Q$. dalechampii (red)

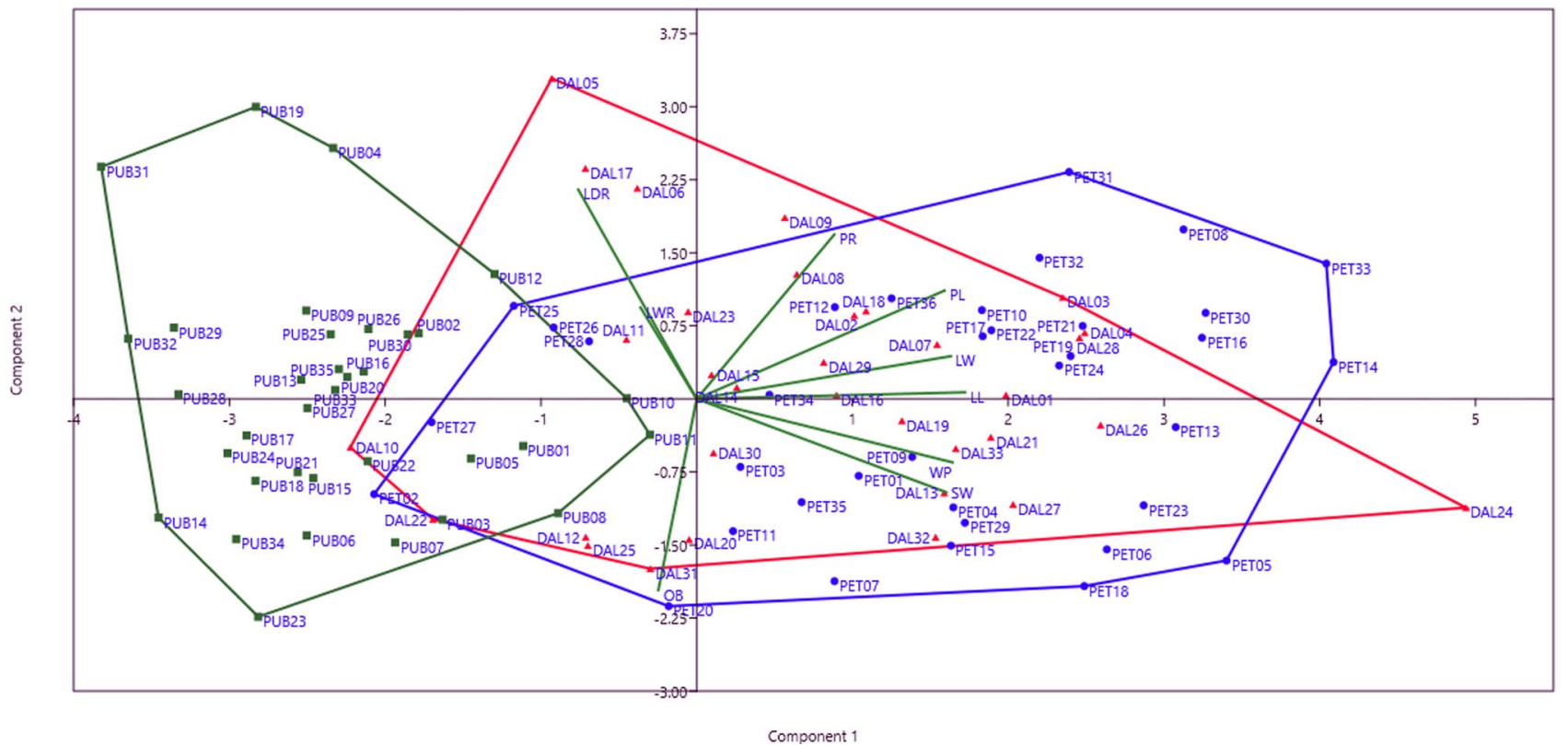

Fig. 7 Scattergram of the 104 trees using the nine variables of leaves. Q. petraea (blue square), Q. pubescens (green triangle), and Q. dalechampii (red dot)

whereas no evident discrimination was observable along the second axis (explaining 21.5\%) (Fig. 8). Wireframe diagrams were produced to graphically display the changes in leaf shape associated with the two main axes. The change in shape was observable by the difference between the starting shape (the average shape deriving from CCM coloured in light blue) and the target shapes (coloured in blue), namely the leaf shapes reflecting the negative (- shape) and positive (+ shape) extremes of the $\mathrm{PC} 1$ and $\mathrm{PC} 2$ axes. 


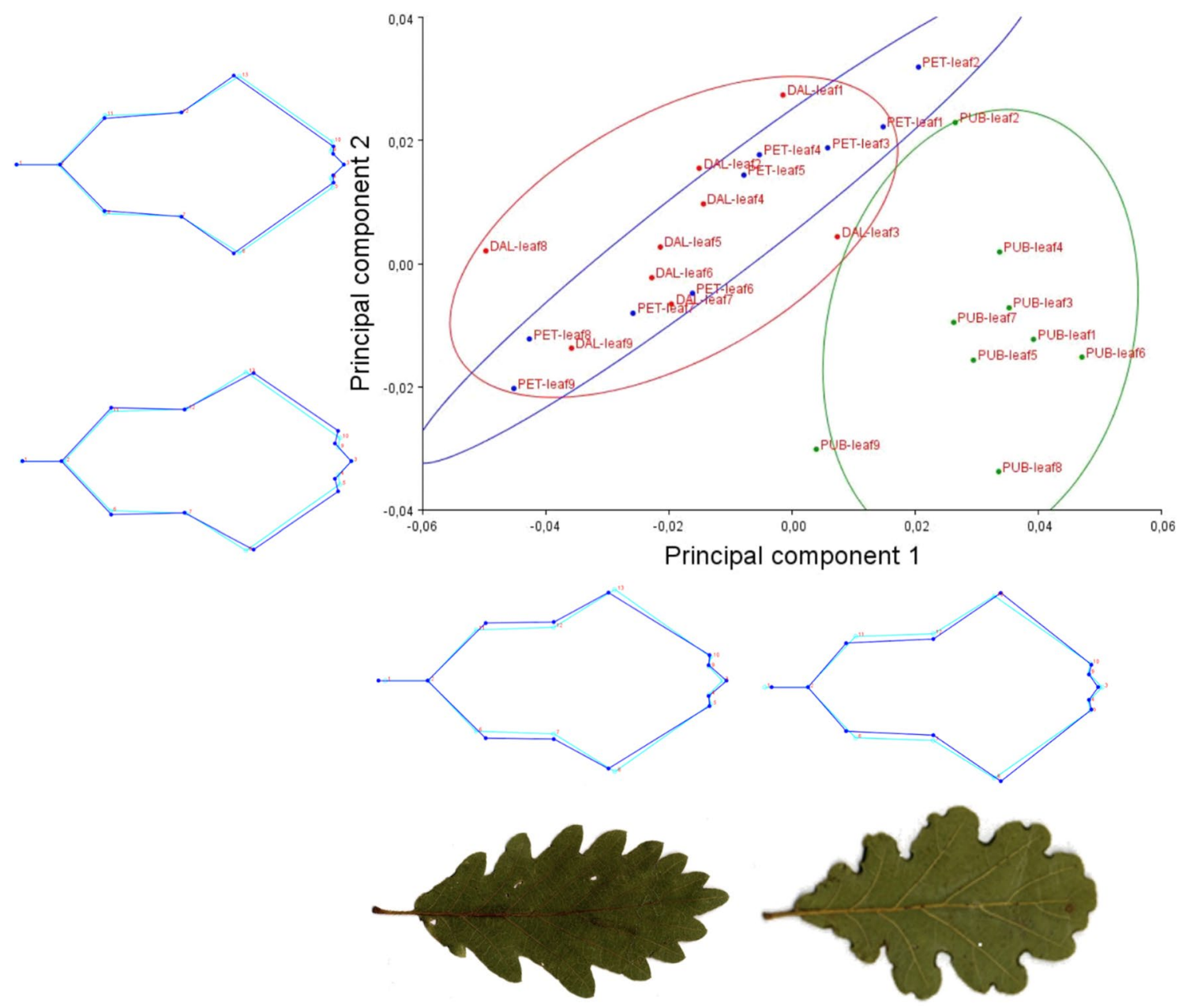

Fig. 8 PCA scatterplot of the first two principal components (PCs) calculated on the symmetric component of the consensus configuration matrix CCM $(n=27)$. Ellipses represent the $90 \%$ confidence interval for equal frequency of the three groups. Extreme leaf shapes

Passing from the negative extreme (scale factor: -0.05 ) to the positive extreme (scale factor of +0.05 ) in PC1, leaf shape changes showed: shortening of the petiole (distance between LM1 and LM2), narrowing of the leaf in the basal region (distance between LM6 and LM11) and approaching of basal lobes to the leaf central rib, narrowing of the leaf in the central region (distance between LM7 and LM12), widening of the leaf in the apical region (distance between LM8 and LM13), and flattening of the apex of the leaf blade (LM3).

In contrast, PC2 was mainly related to the locations of the tips of the lobes (LM5 and LM10) occurring immediately below the apex of the leaf blade and their sinuses (LM4 and LM9). Passing from the negative (scale factor: -0.04) to the positive (scale factor of +0.03 ) extremes, changes of the leaf shape showed: shortening of the distance between LM5 and along PCs are showed through wireframe graphs: starting (average) shape in light blue and target shape in dark blue (scale factor of -0.05 and +0.05 and in PC2 of -0.04 and +0.03 ). Leaf samples are shown only for PC1

LM10 and between LM4 and LM9 and their upward shift and approaching the central rib.

\section{Discussion}

Discrimination at the specific level of species, microspecies, and crypto species of white oaks belonging to the collective groups of Quercus pubescens and Q. petraea and the selection of their diagnostic morphological traits is one of the highest goals for many European taxonomists involved in scientific studies on oaks (even in those not strictly related to taxonomy). Considering both the collective groups, Quercus dalechampii acts as a point of cohesion and at the same time of breaking. The identity of $Q$. dalechampii is a still unsolved systematic issue. Moreover, the nomenclatural 
position and classification of $Q$. dalechampii in terms of collective group was substantially clarified by Di Pietro et al. (2012) with its placement among the pubescent oaks. Taking note of this classification, however, several authors, especially from Eastern Europe, attributed other names to that particular form of sessile oak, which they formerly called $Q$. dalechampii (e.g., $Q$. banatus Kucera, $Q$. petraea subsp. polycarpa Shur), confirming its taxonomic separation from Quercus petraea s.s (Von Raab-Straube and Raus 2013; Kucera 2018). In southern Italy, where the locus classicus of this species is found, a different revisionist path has recently been undertaken, aimed at associating oak living populations or eventually single oak specimens to the name $Q$. dalechampii in such a way as to confirm what was reported. Unfortunately, Michele Tenore was not always clear in his botanical accounts (see Camus 1938-1939; Schwarz 1993; Di Pietro et al. 2012) published in the early decades of the nineteenth century in the Kingdom of Naples when he proposed $Q$. dalechampii as a new species (Tenore 1830, 1831, 1835-1836). To reach this goal, several mixed oak woods of southern Italy, where the abundance of $Q$. dalechampii was certified by published phytosociological papers, were investigated from both a morphological and genetic point of view. These studies involved collecting a high number of populations per sampled area and a high number of individuals per population (Di Pietro et al. 2016, 2020a, b, c). If one of the goals was to identify what could be associated as the 'real' Q. dalechampii (and possibly also the other 'real' pubescent oak species having their locus classicus in southern Italy) within the geographical range for which this (these) species was (were) originally described, the expectations were disappointed. Neither $Q$. dalechampii nor the other species (e.g., $Q$. virgiliana Ten., $Q$. amplifolia Guss., Q. leptobalana Guss., and Q. congesta Presl) showed levels of morphological or genetic diversity that could be distinguished as autonomous species within the collective group of $Q$. pubescens. In contrast to southern Italy, $Q$. dalechampii was reported in the Euganean Hills floristic literature as belonging to the collective group of $Q$. petraea rather than $Q$. pubescens. The geographical isolation of the Euganean Hills in the Po Valley and their ability to host relics of Mediterranean flora could have led to the differentiation and subsequent establishment of a thermophilous ecotype within the $Q$. petraea group, as indeed demonstrated by the phytosociological samples of the $Q$. dalechampii woods, which proved to be richer in Mediterranean species. Finally, as a result of the simultaneous occurrence of $Q$. petraea and $Q$. pubescens in an isolated site, which probably continuously hosted thermophilous oak forest populations during the Quaternary cold periods, the Euganean $Q$. dalechampii could turn out to be a hybrid between the two aforementioned parental species.

Accordingly, we made a preliminary study aimed to outline possible ecological differences between the three species investigated in terms of forest community. This study showed that the woods dominated by $Q$. dalechampii slightly differed from those dominated by $Q$. petraea in being slightly less acidophilic and more thermophilous, suggesting that they might belong to Quercetalia pubescentipetraeae instead of Quercetalia roboris. Although thermophilous, $Q$. dalechampii woods differ from $Q$. pubescens woods (also thermophilous) in that they are developed on acidic substrates.

Subsequently, based on data modelling of morphological traits, we identified possible differentiations between populations belonging to the collective groups of $Q$. pubescens and $Q$. petraea. In particular, this study addressed the significance of morphological assignment by means of univariate and multivariate statistical analysis of macro- and micro-morphological traits on a data set of more than 100 individuals. Moreover, the GMMs approach was applied.

If the above hypotheses were correct, our morphological analyses should have shown us the occurrence of three morphotypes. Instead, what emerged by the univariate analyses of unmeasurable characteristics and the multivariate analysis performed on the leaf and fruit morphological traits was the distribution of individuals within only two groups. One of these two groups turned out to be composed almost exclusively of the individuals of $Q$. pubescens, whereas the other group was found to comprise both the individuals of $Q$. petraea and those of $Q$. dalechampii. The two groups were not totally exclusive, i.e., that in each of the analyses carried out, we always found one or two individuals of $Q$. pubescens that crossed over into the $Q$. dalechampii-Q petraea group and vice versa. This could indicate the occurrence of individuals carrying intermediate morphological traits classifiable as hybrids. This hypothesis, however, would seem not to be supported by the evidence that the individuals who cross over, in both directions, were found to be not the same individuals passing over from one type of analysis to another. For example, individuals of $Q$. pubescens who segregated in the $Q$ dalechampii- $Q$ petraea group were PUB08, PUB10, PUB11, and PUB12 when considering the cluster analysis based on the leaf traits (Fig. 6), PUB 30, PUB33, and PUB34 when considering the one based on fruit characteristics (Fig. 4), and PUB13 when considering that based on the type of pubescence of leaves and twigs (Fig. 3). Conversely, individuals of the $Q$ dalechampii- $Q$ petraea group who segregated in the $Q$. pubescens group were DAL10, DAL11, DAL22, and DAL25 when considering the cluster analysis based on the leaf traits (Fig. 6), no individuals when considering the one based on the fruit traits (Fig. 4), and DAL10, DAL17, DAL26, PET02, PET14, PET25, and PET27 when considering that based on the type of pubescence of leaves and twigs (Fig. 3). In general, the group of $Q$. pubescens acts as a morphologically more homogeneous group than the group $Q$. dalechampii-Q. petraea. For example, in the 
PCA based on the morphological traits of the fruit (Fig. 5), the individuals of $Q$. pubescens formed an isolated group on the left side of the diagram, where instead the individuals of $Q$. dalechampii and $Q$. petraea showed an almost total overlap. Similarly, there was an overlap in the PCA based on the morphological traits of the leaves, although in this case, the degree of overlap was higher and partially involved the $Q$. pubescens group. The greater morphological uniformity of $Q$. pubescens represents an interesting novelty in the context of Italian deciduous oaks. Moreover, it is apparently in contrast with what was observed in the deciduous mixed oak populations of the central and southern Apennines where it was instead $Q$. pubescens that always showed the greatest morphological and genetic variability (Fortini et al. 2015; Guarino et al. 2015; Pasta et al. 2016). As far as the diagnostic role of single morphological traits is concerned, we have been unable to select any trait that is able to distinguish $Q$. dalechampii from $Q$. petraea. Almost all morphological traits of leaves, fruits, and type of pubescence, both dimensional and dimensionless, showed statistically significant differences when comparisons were made between $Q$. petraea and $Q$. pubescens or $Q$. dalechampii and $Q$. pubescens. Furthermore, differences were non-existent, or in any case statistically not significant when the comparison was made between $Q$. dalechampii and $Q$. petraea (Online Resources $5,6,7)$. Only in a very few cases were significant differences not expressed between the joined group $Q$. petraea- $Q$. dalechampii and $Q$. pubescens, but they were expressed by $Q$. petraea or $Q$. dalechampii only. Even the observation of the bark features did not show substantial differences when comparing the individuals of $Q$. petraea and those of $Q$. dalechampii, while the differences were greater when comparing these two species with $Q$. pubescens (Online Resources 9, $10,11)$. These results seem not to confirm the presence of a third species (in this case $Q$. dalechampii) in the study area to be added to the already known $Q$. pubescens and $Q$. petraea.

The occurrence of the two groups was also detectable using a 'size-free' geometric morphometrics approach, which has already proved to be a usable tool for the discrimination of the main white oaks in the Apennines (Viscosi et al. 2009a, b, 2012; Viscosi and Fortini 2011). The leaves of $Q$. pubescens were grouped on the right side of the ordination diagram (Fig. 8) and exhibited a lower degree of variability compared to the groups of $Q$. dalechampii and $Q$. petraea. The latter also showed a significant overlap. The progressive change in leaf shape passing from the group of $Q$. petraea to that of $Q$. pubescens was observed along component 1 (Fig. 8) and can be summarised as the tendency to pass from an oval to a more obverse shape outline, the flattening and widening of the leaf apex, and the slight shortening of the petiole. These results agree with what was already known about the differential leaf traits between $Q$. petraea and $Q$. pubescens, as expressed in the main European flora and illustrated tree guides. However, it emerged that the shape of the base of the leaf, a characteristic generally considered as bearing high diagnostic power to distinguish $Q$. petraea from the other European white oaks, showed great variability (Online Resource 8). Of the nine types of leaf bases proposed in Kremer et al. (2002), we recognised six, and all were found in the three populations investigated. This evidence confirms how the great variability of leaf traits within $Q$. petraea-Q. pubescens may represent a great source of uncertainty and misinterpretations in the identification and subsequent classification stage. In the taxonomic literature on Italian oaks, the problems linked to great leaf variability have been most often associated with the $Q$. pubescens collective group (Bruschi et al. 2000; Borazan and Babac 2003; Fortini et al. 2013, 2015). Instead, it was evident that these problems of identification are extended to $Q$. petraea. It is likely that Camus (1938-1939), when she was about to describe as many as 15 different varieties of $Q$. petraea based on the variability of the leaf shape (which would have risen to 21 when considering the variability of the fruit), was simply noting the great difficulty of associating this species to a univocal leaf pattern.

Regarding the separation between the two collective groups of $Q$. pubescens and $Q$. petraea, the characteristics linked to the type of trichomes occurring on buds, twigs, and leaves were more diagnostic, not only for quick identification and a broad classification of individuals but also to hypothesise the presence of hybrids. Eu-glandular trichomes proved to be diagnostic in distinguishing between different oak species, as well as were extremely uniform within species. In particular, the abaxial leaf surface of $Q$. petraea was characterised by stellate trichomes, whereas that of $Q$. pubescens by simple and fasciculate trichomes (Fig. 9) (Hardin

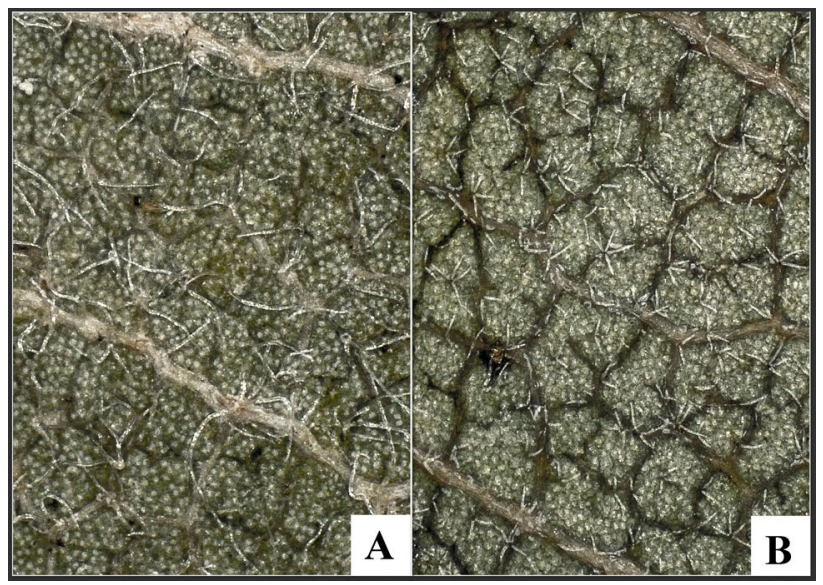

Fig. 9 Examples of fasciculate trichome type ( $Q$. pubescensPUB32) (A) stellate trichome type (Q. petraea-PET21) (B). Abaxial leaf surface. $\times 35$ magnification 
1979; Bussotti and Grossoni 1997; Tschan and Denk 2012; Fortini et al. 2009, 2013). From the study of the type of pubescence performed on the entire dataset (104 individuals), five individuals (PUB13, DAL11, DAL15, DAL17, and DAL25) displayed the simultaneous occurrence of glabrous twigs and fasciculate trichomes on the abaxial leaf surface, sometimes mixed with stellate ones. For these individuals, a hybrid origin could be hypothesised, which should be verified through a genetic study of these populations. This datum, although provisional, is nevertheless interesting, because it allows two types of considerations. The first one concerns the fact that four of five of the possible hybrids would belong to $Q$. dalechampii, thus justifying, at least in part, repeatedly mentioned hypothesis of the occurrence of a presumed third deciduous oak species in the Euganean Hills area (obviously not considering the well-identifiable $Q$. robur occurring in the alluvial plains). The second consideration concerns the evidence that a coexistence in situations of close sympatry (probably never interrupted even in the coldest periods of the Quaternary) of two closely related and potentially interfertile white oak species ( $Q$. pubescens and $Q$. petraea) has given rise to a very limited number of individuals that could be interpreted as hybrids. This would confirm the theory that hypothesises the occurrence of inhibitory mechanisms (Lepais et al. 2009, 2013; Abadie et al. 2012) that allow species to maintain a sufficient degree of autonomy between different European white oak species, despite the lack of full reproductive barriers between them as evidenced in many papers (Curtu et al. 2007; Lepais et al. 2009; Salvini et al. 2009; Gerber et al. 2014; Antonecchia et al. 2015). Difficulty in producing hybridisation and phenotypic diversification between $Q$. petrae $a$ and $Q$. pubescens could be related to the fact that the Euganean Hills act as an archipelago whose woods are isolated many kilometres from similar oak woods and increased by the divergence in flowering time (Salvini et al. 2009; Dupouey and Badeau 1993) and ecological requirements.

\section{Conclusions}

This work investigated the populations of deciduous oaks of the Euganean Hills from a morphological and ecological point of view. In this area, the occurrence of a third deciduous oak species, namely Quercus dalechampii, was reported alongside $Q$. petraea and $Q$. pubescens. To evaluate the possible autonomy of $Q$. dalechampii, a high number of individuals from the populations of the three aforementioned species were analysed from the micro- and macro-morphological point of view, as well as through the geometric morphometric approach. The results of this research clarified some outstanding points. In particular, it was confirmed that the entity reported in the botanical literature of the Euganean
Hills as $Q$. dalechampii belongs to the $Q$. petraea group. For this reason, the name of this presumed taxon cannot in any way be $Q$. dalechampii, as the latter was definitively assigned by Di Pietro et al. (2012) to the downy oaks ( $Q$. pubescens collective group). All observations and statistical analyses carried out in this paper, from the morphological ones to those of geometric morphometry, showed that the oak individuals were classified within two main groups and that there were no particular reasons for not considering these taxa as falling within the natural morphological variability of $Q$. petraea and $Q$. pubescens. Almost all individuals classified a priori as $Q$. dalechampii showed morphological features not sufficiently distinct from those of $Q$. petraea. For this reason, the presence of a second taxon belonging to the group of $Q$. petraea in the Euganean Hills area did not find confirmation in this study. Instead, the occurrence of a population belonging to the $Q$. petraea group showing ecological features that are more thermophilous than those usually showed by $Q$. petraea was confirmed. The type of pubescence occurring on the abaxial leaf surface and twigs was confirmed as the most discriminating characteristic in the identification of the different species belonging to the European white oaks. Precisely, based on the study of the trichomes, we highlighted some (few) individuals characterised by a type of pubescence intermediate between that of $Q$. pubescens and $Q$. petraea that could prove to be of hybrid origin. Genetic studies in progress, which examine a much larger area, will provide a certain answer on this question and will perhaps succeed in highlighting possible phylogeographic links between the deciduous oak populations of the Euganean Hills and those of the surrounding areas.

Supplementary Information The online version contains supplementary material available at https://doi.org/10.1007/s12210-021-01001-4.

Funding Open access funding provided by Università degli Studi di Roma La Sapienza within the CRUI-CARE Agreement.

Open Access This article is licensed under a Creative Commons Attribution 4.0 International License, which permits use, sharing, adaptation, distribution and reproduction in any medium or format, as long as you give appropriate credit to the original author(s) and the source, provide a link to the Creative Commons licence, and indicate if changes were made. The images or other third party material in this article are included in the article's Creative Commons licence, unless indicated otherwise in a credit line to the material. If material is not included in the article's Creative Commons licence and your intended use is not permitted by statutory regulation or exceeds the permitted use, you will need to obtain permission directly from the copyright holder. To view a copy of this licence, visit http://creativecommons.org/licenses/by/4.0/.

\section{References}

Abadie P, Roussel G, Dencausse B, Bonnet C, Bertocchi E, Louvet JM, Kremer A, Garnier-Géré P (2012) Strength, diversity and 
plasticity of postmating reproductive barriers between two hybridizing oak species (Quercus robur L. and Quercus petraea (Matt) Liebl.). J Evol Biol 25:157-173. https://doi.org/10.1111/j.14209101.2011.02414.x

Addinsoft (2020) XLSTAT statistical and data analysis solution. Paris, France. https://www.xlstat.com. Accessed 5 Nov 2020

Antonecchia G, Fortini P, Lepais O, Gerber S, Legér P, Scippa GS, Viscosi V (2015) Genetic structure of a natural oak community in central Italy: evidence of gene flow between three sympatric white oak species (Quercus, Fagaceae). Ann For Res 58(2):205-216. https://doi.org/10.15287/afr.2015.415

Argenti C, Masin R, Pellegrini B (2019) Flora del Veneto, vol 2. Cierre Edizioni, Caselle (TV)

ARPAV (2013) Carta dei suoli della provincia di Padova. Osservatorio Regionale Suolo, Treviso

Bartolucci F, Peruzzi L, Galasso G, Albano A, Alessandrini A, Ardenghi NMG, Astuti G, Bacchetta G, Ballelli S, Banfi E, Barberis G, Bernardo L, Bouvet D, Bovio M, Cecchi L, Di Pietro R, Domina G, Fascetti S, Fenu G, Festi F, Foggi B, Gallo L, Gottschlich G, Gubellini L, Iamonico D, Iberite M, JiménezMejías P, Lattanzi E, Marchetti D, Martinetto E, Masin RR, Medagli P, Passalacqua NG, Peccenini S, Pennesi R, Pierini B, Poldini L, Prosser F, Raimondo FM, Roma-Marzio F, Rosati L, Santangelo A, Scoppola A, Scortegagna S, Selvaggi A, Selvi F, Soldano A, Stinca A, Wagensommer RP, Wilhalm T, Conti F (2018) An updated checklist of the vascular flora native to Italy. Pl Biosyst 152:179-303. https://doi.org/10.1080/11263504.2017.1419996

Biondi E, Casavecchia S, Pesaresi S (2010) Interpretation and management of the forest habitats of the Italian peninsula. Acta Bot Gall 157(4):687-719. https://doi.org/10.1080/12538078.2010.10516 242

Borazan A, Babac MT (2003) Morphometric leaf variation in oaks (Quercus) of Bulu, Turkey. Ann Bot Fenn 40:233-242

Braun-Blanquet J (1964) Pflanzensoziologie. Grundzüge der Vegetationskunde. Springer Verlag, Wien, AT

Brullo S, Guarino R, Siracusa G (1999) Revisione tassonomica delle querce caducifoglie della Sicilia. Webbia 54(1):1-72. https://doi. org/10.1080/00837792.1999.10670670

Bruschi P, Vendramin GG, Bussotti F, Grossoni P (2000) Morphological and molecular differentiation between Quercus petraea (Matt.) Liebl. and Quercus pubescens Willd. (Fagaceae) in northern and central Italy. Ann Bot 85:325-333. https://doi.org/10.1006/anbo. 1999.1046

Buffa G, Lasen C (2010) Atlante dei siti Natura 2000 nel Veneto. Regione del Veneto

Buffa G, Del Vecchio S, Acosta ATR (2016) Box 6: Il metodo del transetto di vegetazione. In: Angelini P, Casella L, Grignetti A, Genovesi P (eds) Manuali per il monitoraggio di specie e habitat di interesse comunitario (Direttiva 92/43/CEE) in Italia: Habitat, ISPRA, Serie Manuali e Linee Guida, 142/2016

Burger WC (1975) The species concept in Quercus. Taxon 24:45-50. https://doi.org/10.2307/1218998

Bussotti F, Grossoni P (1997) European and Mediterranean oaks (Quercus L.; Fagaceae): SEM characterization of the micromorphology of the abaxial leaf surface. Bot J Linn Soc 124:183-199. https://doi.org/10.1111/j.1095-8339.1997.tb01789.x

Camus A (1938-1939) Monographie du genre Quercus. Tome II. Genre Quercus. Sous-genre Euquercus (sections Lepidobalanus et Macrobalanus). Editions Paul Lechevalier (Paris). Encyclopédie économique de sylviculture VII

Carli E, Massimi M, Angelini P, Casella L, Attorre F, Agrillo E (2020) How to improve the distribution maps of habitat types at national scale. Rendi Fis Acc Lincei 31(3):881-888. https://doi.org/10. 1007/s12210-020-00917-7

Caudullo G, Oliveira S, De Rigo D (2016) Quercus robur and Quercus petraea in Europe: distribution, habitat, usage and threats E Eaton,
G. In: San-Miguel-Ayanz J, De Rigo D, Caudullo G, Houston Durrant T, Mauri A (eds) European Atlas of Forest Tree Species. Publications Office of the European Union, Luxembourg, p e01493b+

Costantini D, Lasen C, Minelli A, Rallo G, Turin P, Viola F (2005) Progetto LIFE03 NAT/IT/000119. Salvaguardia di habitat di interesse ecologico nei Colli Euganei. Piano di monitoraggio. Parco Regionale dei Colli Euganei, Este (PD)

Curtu A, Gailing O, Finkeldey R (2007) Evidence for hybridization and introgression within a species-rich oak (Quercus spp.) community. BMC Evol Biol 7:218. https://doi.org/10.1186/1471-2148-7-218

Di Pietro R, Viscosi V, Peruzzi L, Fortini P (2012) A review of the application of the name Quercus dalechampii. Taxon 61:13111316. https://doi.org/10.1002/tax.616012

Di Pietro R, Di Marzio P, Medagli P, Misano G, Silletti GN, Wagensommer RP, Fortini P (2016) Evidence from multivariate morphometric study of the Quercus pubescens complex in southeast Italy. Bot Serb 40:83-90. https://doi.org/10.5281/zenodo.48865

Di Pietro R, Di Marzio P, Antonecchia G, Conte AL, Fortini P (2020a) Preliminary characterization of the Quercus pubescens complex in southern Italy using molecular markers. Acta Bot Croat 79(1):1525. https://doi.org/10.37427/botcro-2020-002

Di Pietro R, Conte AL, Di Marzio P, Fortini P, Farris E, Gianguzzi L, Müller M, Rosati L, Spampinato G, Gailing O (2020b) Does the genetic diversity among pubescent white oaks in southern Italy, Sicily and Sardinia islands support the current taxonomic classification. Eur J for Res. https://doi.org/10.1007/s10342-020-01334-Z

Di Pietro R, Conte AL, Di Marzio P, Gianguzzi L, Spampinato G, Caldarella O, Fortini P (2020c) A multivariate morphometric analysis of diagnostic traits in southern Italy and Sicily pubescent oaks. Folia Geobot. https://doi.org/10.1007/s12224-020-09378-0

Dupouey JL, Badeau V (1993) Morphological variability of oaks $(Q$. robur L., Q. petraea (Matt.) Liebl., $Q$. pubescens Willd.) in a northeastern France: preliminary results. Ann Sci for 50:35s-40s

European Commission DG Environment (2014) Interpretation manual of European Union habitats. Eur 28. Nature ENV B.3. http://ec. europa.eu/environment/nature/legislation/habitatsdirective/docs/ Int_Manual_EU28.pdf

Fontana A, Mozzi P, Bondesan A (2010) Late pleistocene evolution of the Venetian-Friulian Plain. Rend Fis Acc Lincei 21:181-196. https://doi.org/10.1007/s12210-010-0093-1

Fortini P, Viscosi V, Fineschi S, Vendramin GG (2009) Comparative leaf surface morphology and molecular data of five oaks of subgenus Quercus Oerst. (Fagaceae). Plant Biosyst 143:543-554. https://doi.org/10.1080/11263500902722980

Fortini P, Antonecchia G, Di Marzio P, Maiuro L, Viscosi V (2013) Role of micromorphological leaf traits and molecular data in taxonomy of three sympatric white oak species and their hybrids (Quercus L.). Plant Biosyst 149(3):546-558. https://doi.org/10. 1080/11263504.2013.868374

Fortini P, Di Marzio P, Di Pietro R (2015) Differentiation and hybridization of Quercus frainetto, $Q$. petraea, and $Q$. pubescens (Fagaceae): insights from macro-morphological leaf traits and molecular data. Plant Syst Evol 301:375-385. https://doi.org/10. 1007/s00606-014-1080-2

Gerber S, Chadoeuf J, Gugerli F, Lascoux M, Buiteveld J, Cottrell J, Dounavi A, Fineschi S, Forrest LL, Fogelqvist J, Goicoechea PG, Jensen JS, Salvini D, Vendramin GG, Kremer A (2014) High rates of gene flow by pollen and seed in oak populations across Europe. PLoS ONE 9(1):e85130. https://doi.org/10.1371/journal. pone.0085130

Gigante D, Acosta ATR, Agrillo E, Armiraglio S, Assini S, Attorre F, Bagella S, Buffa G, Casella L, Giancola C, Giusso del Galdo GP, Marcenò C, Pezzi G, Prisco I, Venanzoni R, Viciani D (2018) Habitat conservation in Italy: the state of the art in the light of the first European red list of terrestrial and freshwater habitats. 
Rend Fis Acc Lincei 29(2):251-265. https://doi.org/10.1007/ s12210-018-0688-5

Gonzàles-Rodrìguez A, Arias DM, Oyama K (2004) Morphological and RAPD analysis of hybridization between Quercus affinis and $Q$. laurina (Fagaceae), two Mexican red oaks. Am J Bot 91(3):499-509. https://doi.org/10.3732/ajb.91.3.401

Guarino R, Bazan G, Paura B (2015) Downy-oak woods of Italy: phytogeographical remarks on a controversial taxonomic and ecologic issue. In: Box E, Fujiwara K (eds) Warm-temperate deciduous forests around the northern hemisphere. Geobotany studies (basics, methods and case studies). Springer, Berlin, pp 139-151. https:// doi.org/10.1007/978-3-319-01261-2-7

Gubler M, Henne PD, Schwörer C, Boltshauser-Kaltenrieder P, André F, Lotter AF, Brönnimann S, Tinner W (2018) Microclimatic gradients provide evidence for a glacial refugium for temperate trees in a sheltered hilly landscape of Northern Italy. J Biogeogr 45(11):2564-2575. https://doi.org/10.1111/jbi.13426

Gugerli F, Walser JC, Dounavi K, Holderegger R, Finkeldey R (2007) Coincidence of small-scale spatial discontinuities in leaf morphology and nuclear microsatellite variation of Quercus petraea and Q. robur in a mixed forest. Ann Bot 99:713-722. https://doi.org/ $10.1093 / \mathrm{aob} / \mathrm{mcm} 006$

Hammer Ø, Harper DAT, Ryan PD (2001) Past: paleontological statistics software package for education and data analysis. Palaeontologia Electronica 4(1):art. 4

Hardin JW (1979) Patterns of variation in foliar trichomes of eastern North American Quercus. Am J Bot 66:576-585. https://doi.org/ $10.2307 / 2442507$

Hipp AL (2015) Should hybridization make us skeptical of the oak phylogeny? Int Oaks 26:9-17

Hipp AL et al (2019) Genomic landscape of the global oak phylogeny. New Phytol. https://doi.org/10.1111/nph.16162

Kissling P (1983) Les chênaies du Jura central suisse (Oak forests of central Jura canton). Thesis, Université de Lausanne, Switzerland (in French)

Klingenberg CP (2011) MorphoJ: an integrated software package for geometric morphometrics. Mol Ecol Resour 11:353-357

Klingenberg CP, Duttke S, Whelan S, Kim M (2012) Developmental plasticity, morphological variation and evolvability: a multilevel analysis of morphometric integration in the shape of compound leaves. J Evol Biol 25:115-129. https://doi.org/10.1111/j.14209101.2011.02410.x

Kremer A, Dupouey J, Deans JD, Cottrell J, Csaikl U et al (2002) Leaf morphological differentiation between Quercus robur and Quercus petraea is stable across western European mixed oak stands. Ann for Sci 59(7):777-787. https://doi.org/10.1051/forest:2002065

Kucera P (2018) New name for Central Europaean oak formerly labelled as Quercus dalechampii. Biologia 73:313-317. https:// doi.org/10.2478/s11756-018-0048-z

Lepais O, Petit RJ, Guichoux E (2009) Species relative abundance and direction of introgression in oaks. Mol Ecol 18:2228-2242. https://doi.org/10.1111/j.1365-294X.2009.04137.x

Lepais O, Muller SD, Ben Saad-Limam S, Benslama M, Rhazi L, Belouahem-Abed D et al (2013) High genetic diversity and distinctiveness of rear-edge climate relicts maintained by ancient tetraploidisation for Alnus glutinosa. PLoS ONE 8(9):e75029. https://doi.org/10.1371/journal.pone.0075029

Masin R, Filesi L, Lasen C. Flora del gruppo del M. Ceva e della fascia torbosa di bonifica del "Ferro di Cavallo" (Colli Euganei, PD, NE Italia). Natura Vicentina 22 (in press)

Masin R, Tietto C (2005) Flora dei Colli Euganei e della pianura limitrofa. SAPI ed., Padova

Masin R, Tietto C (2006) Flora vascolare della Provincia di Padova. Natura Vicentina 9:7-103
Minihan VB, Rushton BS (1984) The taxonomic status of oaks (Quercus ssp.) in Breen Wood, Co Antrim, Northern Ireland. Watsonia 15:27-32

Mucina L, Bültmann H, Dierßen K, Theurillat JP, Raus T, Čarni A et al (2016) Vegetation of Europe: hierarchical floristic classification system of vascular plant, bryophyte, lichen, and algal communities. Appl Veg Sci 19:3-264. https://doi.org/10.1111/avsc.12257

Muir G, Fleming CC, Schlötterer C (2000) Species status of hybridizing oaks. Nature 405(6790):1016. https://doi.org/10.1038/35016 640

Muir G, Schlotterer C (2005) Evidence for shared ancestral polymorphism rather than recurrent gene flow at microsatellite loci differentiating two hybridizing oaks (Quercus spp.). Mol Ecol 14:549-561. https://doi.org/10.1111/j.1365-294X.2004.02418.x

Musarella CM, Cano-Ortiz A, Pinar Fuentes JC, Navas-Urena J, Pinto Gomes CJ, Quinto-Canas R, Cano E, Spampinato G (2018) Similarity analysis between species of the genus Quercus L. (Fagaceae) in southern Italy based on the fractal dimension. PhytoKeys 113:79-95. https://doi.org/10.3897/phytokeys.113.30330

Pasta S, De Rigo D, Caudullo G (2016) Quercus pubescens in Europe: distribution, habitat, usage and threats. In: San-Miguel-Ayanz, J, De Rigo D, Caudullo G, Houston Durrant T, Mauri A (eds) European atlas of forest tree species. Publications Office of the European Union, Luxembourg, p e01493b

Pellegrini GB (2004) Edifici vulcanici estinti: Colli Euganei. In: A.A. V.V., ITALIA Atlante dei tipi geografici. Ed: Istituto Geografico Militare, Firenze, pp 338-339

Rasband WS (1997-2007) ImageJ, US National Institutes of Health, Bethesda, Maryland, USA. http://rsb.info.nih.gov/ij/

Rohlf FJ (2015) The Tps series of software. Hystrix 26:9

Rohlf FJ (2019) tpsUtil32. Version 1.78 [computer software]. Department of Ecology and Evolution, State University of New York, Stony Brook. https://life.bio.sunysb.edu/morph/

Salvini D, Bruschi P, Fineschi S, Grossoni P, Kjær ED et al (2009) Natural hybridisation between Quercus petraea (Matt.) Liebl. and Quercus pubescens Willd. within an Italian stand as revealed by microsatellite fingerprinting. Plant Biol 11:758-765. https://doi. org/10.1111/j.1438-8677.2008.00158.x

Savriama Y, Klingenberg CP (2011) Beyond bilateral symmetry: geometric morphometric methods for any type of symmetry. BMC Evol Biol 11:280. https://doi.org/10.1186/1471-2148-11-280

Schwarz O (1993) Quercus L. In: Tutin TG, Burges NA, Chater AO, Edmondson JR, Heywood VH, Moore DM, Valentine DH, Walters SM, Webb DA (eds) Flora Europaea. Cambridge University Press, Cambridge, pp 72-76

Silva MFS, De Andrade IM, Mayo SJ (2012) Geometric morphometrics of leaf blade shape in Montrichardia linifera (Araceae) populations from the Rio Parnaíba delta, north-east Brazil. Bot J Linn Soc 170:554-572. https://doi.org/10.1007/s40415-014-0072-3

Spellenberg R (1995) On the hybrid nature of Quercus basaseachicensis (Fagaceae, sect. Quercus). SIDA 16(3):427-434

Tasinazzo S, Fiorentin R (2000) I Boschi dei Colli Berici (Vicenza, NE Italia). Studia Geobotanica 19:3-23

Tenore M (1830) Semina anno 1830 collecta, quae in Horto Botanico Neapolitano pro mutua commutatione offeruntur. Naples: Tipografia Fibreni

Tenore M (1831) Florae neapolitanae sylloge. Naples: Tipografia Fibreni

Tenore M (1835-1836) Flora napolitana, vol 5. Stampa Reale

Thiers B (2015) Index Herbariorum: A global directory of public herbaria and associated staff. New York Botanical Garden's Virtual Herbarium. http://sweetgum.nybg.org/ih/

Tschan G, Denk T (2012) Trichome types, foliar indumentums and epicuticular wax in the Mediterranean gall oaks, Quercus subsection Galliferae (Fagaceae): Implications for taxonomy, ecology, and evolution. Bot J Linn Soc 169:611-644 
Valbuena-Carabaña M, González-Martínez S, Sork VL, Collada C, Soto A, Goicoechea PG et al (2005) Gene flow and hybridisation in a mixed oak forest (Quercus pyrenaica Willd. and Quercus petraea (Matts.) Liebl.) in central Spain. J Hered 95:457-465. https://doi.org/10.1038/sj.hdy.6800752

Valbuena-Carabaña M, González-Martínez SC, Hardy OJ, Gil L (2007) Fine-scale spatial genetic structure in mixed oak stands with different levels of hybridization. Mol Ecol 16:1207-1219. https:// doi.org/10.1111/j.1365-294X.2007.03231.x

Viscosi V (2015) Geometric morphometrics and leaf phenotypic plasticity: assessing fluctuating asymmetry and allometry in European white oaks (Quercus). Bot J Linn Soc 179:335-348. https://doi. org/10.1111/boj.12323

Viscosi V, Fortini P, Slice DE, Loy A, Blasi C (2009a) Geometric morphometric analyses of leaf variation in four oak species of the subgenus Quercus (Fagaceae). Plant Biosyst 143(3):575-587. https://doi.org/10.1080/11263500902775277

Viscosi V, Lepais O, Gerber S, Fortini P (2009b) Leaf morphological analyses in four European oak species (Quercus) and their hybrids: a comparison of traditional and geometric morphometric methods. Plant Biosyst 143(3):564-574. https://doi.org/10.1080/ 11263500902723129

Viscosi V, Fortini P (2011) Leaf shape variation and differentiation in three sympatric white oak species revealed by elliptic Fourier analysis. Nord J Bot 29:632-640. https://doi.org/10.1111/j.17561051.2011.01098.x

Viscosi V, Antonecchia G, Lepais O, Fortini P, Gerber S, Loy A (2012) Leaf shape and size differentiation in white oaks: assessment of allometric relationships among three sympatric species and their hybrids. Int J Plant Sci 173(8):875-884. https://doi.org/10.1086/ 667234

Von Raab-Straube E, Raus T (2013) Euro+Med-Checklist Notulae, 1. Willdenowia 43:159. https://doi.org/10.3372/wi.43.43118

Publisher's Note Springer Nature remains neutral with regard to jurisdictional claims in published maps and institutional affiliations. 